\title{
GROWTH PERFORMANCE, BLOOD METABOLITES AND CARCASS TRAITS OF GROWING LAMBS RAISED ON BERSEEM SILAGE RATION \\ Gabr, A. A. ${ }^{1}$; M. A. A. Abd El-Hady ${ }^{2}$; S. A. El-Ayouty ${ }^{1}$ and M. A. Z. Shahin ${ }^{1}$ \\ ${ }^{1}$ Animal Production Dept., Fac. Agric., Mans. Univ., Egypt. \\ ${ }^{2}$ Animal Production Res. Inst., Agric. Res. Center, Dokki, Giza, Egypt. \\ E-mail: magid_70@hotmail.com
}

\begin{abstract}
This study was conducted to determine growth performance, feed efficiency, feed utilization, blood metabolites and carcass characteristics of growing lambs raised on berseem silage treated with formic acid and concentrate feed mixture (CFM) ration. Berseem clover was chopped at $2-3 \mathrm{~cm}$ of length and wilted for $24 \mathrm{hr}$ then ensiled with $0.5 \%$ formic acid treatment (BSF). After 60 days from ensiling process, fermentation characteristics of ensiled berseem were immediately examined. Twelve growing crossbreed lambs were randomly assigned to two groups. First group (6 lambs; $23.0 \pm 1.68 \mathrm{~kg}$ ) was raised on starter concentrate feed mixture (CFM) plus berseem hay as a control ration. The second group (6 lambs; $22.5 \pm 1.68 \mathrm{~kg}$ ) was raised on CFM plus BSF. Growth trial was continued for 6 months. Daily weight gain (DWG), relative growth rate (RGR), voluntary feed intake, feed conversion, economic efficiency, blood parameters were examined. Digestibility trials were conducted in the last month of the experiment to determine the utilization and feeding value of tested rations. At the end of experiment, three lambs of each group were slaughtered to determine carcass traits and anatomy of digestive tract. The main results proposed that lambs raised on BSF plus CFM had higher total gain, DWG and RGR $(P<0.01)$ than that in control group especially in last two months. Feed conversion $(\mathrm{kg} \mathrm{DMl} / \mathrm{kg}$ gain) was better in lambs fed BSF ration than control (8.56 vs. $12.46 \mathrm{~kg}$ ). The most profit and economic efficiency (1.38 LE and $97.5 \%$, respectively) were in BSF group. The most of nutrient digestibility, nutritive value and quality index were higher $(\mathrm{P}<0.05)$ in $\mathrm{BSF}$ ration compared with control ration. Rumen parameters values were higher $(P<0.05)$ in animals fed BSF rationcompared with control ration. Plasma glucose concentration did not differ significantly between two groups, but differed significantly $(\mathrm{P}<0.01)$ with the advancement of age. Whereas, total protein and globulin were $(P<0.05)$ significantly lower in lambs fed BSF ration than those fed control ration. The activity of AST and ALT was $(P<0.05)$ greater in control group than those in BSF group. Hot carcass, longissimus dorsi weight and yield grade value were greater $(\mathrm{P}<0.05)$ in BSF than control. Most of anatomy traits of digestive tract did not differ significantly between two groups. It could be concluded that growing lambs raised on wilted BSF plus CFM had the highest growth performance, feed conversion, economic efficiency, quality index, feed utilization, normal health status and better carcass traits compared with traditional rising system based on berseem hay plus CFM ration.
\end{abstract}

Keyword: Growth performance, blood, carcass, lambs, berseem silage

\section{INTRODUCTION}

Legumes have always been regarded as an important group of crops grown for feeding farm animals because of their nitrogen-fixing properties and because they are a relatively rich source of protein (McDonald et al., 1991). 
Gabr, A. A. et al.

Until recently decade, legumes were regarded as being unsuitable for ensiling as the fermentation was invariably dominated by clostridia, leading to butyrate-type silage. This has been attributed to three factors: firstly they are highly buffered, secondly they tend to be having low water soluble carbohydrate contents and thirdly they are often of low dry matter content (Frame et al., 1998).

Formic acid is widely used to achieve preservation legumes and direct rapid $\mathrm{pH}$ drop of ensiled material and eventually the acidity level is adequate to inhibit or kill most bacteria and other microorganisms. Therefore, addition of formic acid to ensiled material has been reported to have generally positive effects on fermentation (Haigh, 1988 and Snyman et al., 1996). Although, intake and performance of lambs have been found to be positively correlated with grass silage quality (Reed, 1979), lamb performance on grass silage alone is poor unless the silage is of extremely high quality, in terms of digestibility and chemical composition (Webster and Povey, 1990). Forage legumes such as berseem, lucerne and red clover have been shown to have higher intake potential and high protein contents compared to grass (Fraser et al., 2000). The growing lambs offered red clover silage had a higher voluntary silage dry matter intake, total dry matter intake, and metabolisable energy intake and therefore resulted in a faster growth rate and better feed efficiency compared with either lucerne or grass silage (Speijers et al., 2005). Thus, it may be possible for lamb producers to improve the performance of raising lambs by feeding ensiled legumes as the basal feed rather than hay. Berseem clover (Trifolium alexandrinum) could be ensiled as a very good quality silage (Flieg score 90 ) after chopping and wilting for $24 \mathrm{hr}$ (about 20\% DM) with formic acid treatment (Abd El-Hady et al., 2012 $\mathrm{a}_{\mathrm{a}}$.

Little information is available currently on growth performance and carcass traits of growing lambs when fed ensiled forage legumes. Therefore, the objective of this study was to examine effects of raising growing crossbreed lambs fed ensiled wilted berseem treated with formic acid plus CFM compared to berseem hay plus CFM as a traditional summer feeding on growth performance, feed efficiency, feed utilization, carcass characteristics and blood metabolites as a measure of nutritional inadequacy.

\section{MATERIALS AND METHODS}

The present study was carried out at the Experimental Farm of the Animal Production Department, Faculty of Agriculture, Mansoura University. The analytical work was undertaken at the laboratories of department. The object of this study was to evaluate growth performance, feed efficiency, economic efficiency, blood metabolites and carcass characteristics of lambs fed chopped berseem silage, wilted for $24 \mathrm{hr}$ with formic acid treatment as the best treatment of ensiled berseem in the previous study (Abd El-hady et al., 2012a).

\section{Ensiling process:}

About 8 ton of fresh berseem ( $3^{\text {rd }}$ cut) was collected from the field. Berseem (Trifolium alexandrinum L.) was mechanically chopped using 
harvester chopper machine to $2-3 \mathrm{~cm}$ of length. The chopped berseem was wilted for $24 \mathrm{hr}$ to reduce the moisture content to about $73 \%$ before ensiling. Wilted berseem was well pressed in layers using wheel tractor to ensure air removal and formic acid was sprayed on every layer as $0.5 \%(5 \mathrm{l} / \mathrm{ton}$ as fresh matter). After filling of the silo, it was covered by plastic sheet followed by thin layer of rice straw and layer of soil to maintain anaerobic condition of silo. The ensiled berseem was kept for 2 months before feeding animals.

\section{Animals and housing:}

Twelve growing crossbreed male lambs (Rahmany $\mathrm{x}$ Romanouf; 5 months old) of $22.7 \pm 1.19 \mathrm{~kg}$ average live body weight were used in the present study and continued about6 months. The animals were randomly distributed to two experimental groups according to their live body weight. Lambs were kept indoors semi-open stall barn in separated pens. Each pen provided adequate feeding space and drinking facilities. The $1^{\text {st }}$ group $(n=6$; $23.0 \pm 1.68 \mathrm{~kg}$ ) was received $52 \%$ concentrate feed mixture (CFM) and $48 \%$ berseem hay as a control ration of the farm in summer season. Whereas, the $2^{\text {nd }}$ group $(n=6 ; 22.5 \pm 1.68 \mathrm{~kg}$ ) was offered $46 \%$ CFM plus $54 \%$ berseem silage treated with formic acid. The amount of berseem hay fed was reduced by approximately $15 \%$ per day over a 7 days period, and the amount of silage fed was increased similarly. The CFM contained, on an air dry basis, $36 \%$ yellow corn, $22 \%$ soybean meal (44\% CP), $15 \%$ linseed cake, $22 \%$ wheat bran, $3 \%$ molasses, $1.5 \%$ calcium carbonate and $0.5 \%$ sodium chloride. The chemical composition of CFM, berseem hay and silage were shown in Table (1). The CFM, berseem silage and hay were offered twice daily according to NRC (1985). The feed intake was increased gradually according to increase body weight. Mineral blocks were available free choice for all animals under the experiment. All lambs were vaccinated with Covexin 8 and injected subcutaneously with Ivomecas anti-gastrointestinal parasites. Lambs were shaved their wool at the beginning of the experiment. Lambs were weighted biweekly for measuring growth performance. Feed was withheld overnight before weighing. The lambs were fed on the experimental ration for about 180 days. Intake and feed conversion were determined on a fresh basis.

\section{Blood sampling:}

Blood samples from each experimental animal were collected every month via jugular vein using heparinized tubes. Blood plasma was separated by centrifugation at 3000 r.p.m for 10 minutes and stored at $-20^{\circ} \mathrm{C}$ until analyzed for the different blood parameters. Plasma glucose, total protein, albumin, createnine and aminotransferases (AST and ALT) were determined calorimetrically using commercial kits according to the procedures outlined by the manufacture. 
Gabr, A. A. et al.

Table (1): Fermentation quality of berseem silage and chemical composition (\% as DM) of ingredients and calculated experimental rations that fed growing lambs.

\begin{tabular}{|c|c|c|c|c|c|}
\hline \multirow[t]{2}{*}{ Items } & \multirow{2}{*}{ CFM } & \multirow{2}{*}{ Hay } & \multirow{2}{*}{ BSF } & \multicolumn{2}{|c|}{ Experimental rations } \\
\hline & & & & R1 & R2 \\
\hline DM\% & 86.2 & 86.8 & 27.7 & 84.02 & 38.96 \\
\hline \multicolumn{6}{|l|}{ Silage quality } \\
\hline pH value & - & - & 4.2 & - & - \\
\hline Lactic acid\% & - & - & 2.86 & - & - \\
\hline $\mathrm{NH}_{3}-\mathrm{N}, \mathrm{mg} / \mathrm{dl}$ & - & - & 6.3 & - & - \\
\hline \multicolumn{6}{|c|}{ Chemical composition \% } \\
\hline OM & 94.07 & 89.73 & 83.68 & 92.0 & 88.1 \\
\hline CP & 17.63 & 13.60 & 16.39 & 15.71 & 16.92 \\
\hline EE & 3.53 & 1.92 & 2.49 & 2.76 & 2.93 \\
\hline CF & 11.84 & 26.33 & 35.01 & 18.74 & 25.14 \\
\hline NFE & 61.07 & 47.88 & 29.79 & 54.79 & 43.11 \\
\hline Ash & 5.93 & 10.27 & 16.32 & 8.00 & 11.90 \\
\hline NDF & 31.12 & 46.44 & 43.58 & 38.42 & 38.27 \\
\hline ADF & 14.56 & 28.96 & 27.29 & 21.42 & 21.86 \\
\hline Hemicellulose & 16.56 & 17.48 & 16.29 & 17.83 & 16.41 \\
\hline Cellulose & 9.02 & 21.41 & 19.70 & 14.92 & 15.15 \\
\hline ADL & 5.54 & 7.55 & 7.58 & 6.49 & 6.71 \\
\hline NFC & 40.84 & 26.21 & 18.2 & 33.87 & 27.84 \\
\hline
\end{tabular}

\section{Digestibility trials:}

Two digestibility trials were conducted using three ram lambs to determine nutrients digestibility coefficients and nutritive values of the experimental rations at the last month of feeding trial. Lambs were housed in metabolic cages during the digestibility trial. No problems with feet, legs, stiffness or health of the lambs were noticed. Feeding of the lambs was done as described for lambs in the growth trial. Animals were fed to cover the requirements of growing lambs according to NRC (1985). The average of body weight of lambs was $39.2 \pm 0.84 \mathrm{~kg}$ at 10 months of age.

Feed was offered ad libitum throughout the trialtwice daily (at 8.0 AM and 4.0 PM) and voluntary intake was measured daily by difference between fed and residual. Drinking water was available to each animal allover the time. Samples of feeds were taken in the first and last of experiment and kept for later analysis. Daily output of feces was determined and a $10 \%$ subsamples was composited by animal and frozen during the collection period of each trial (5 days). Feces samples were dried in forced air oven at $65^{\circ} \mathrm{C}$ for $48 \mathrm{hr}$ and kept for ground and chemical analysis.

\section{Rumen fermentation:}

Rumen fluid samples were collected from all experimental lambs during the last day of the digestion trial. The samples were taken by rubber stomach tube using gentle mouth suction. About $100 \mathrm{ml}$ of rumen fluid was collected just before offering the morning feed (zero time), thereafter at 2 and $4 \mathrm{hr}$ post feeding (at timed interval). The collected samples were filtered through 4 layers of surgical gauze and were immediately used to determine rumen $\mathrm{pH}$ using digital $\mathrm{pH}$-meter with a combined electrode. The effective natural detergent fiber (eNDF) was calculated according to Fox et al. (2000).Then 
samples were stored in dried bottles at $-20^{\circ} \mathrm{C}$ for measuring other parameters. Ammonia nitrogen $\left(\mathrm{NH}_{3}-\mathrm{N}\right)$ concentration was measured according to Conway (1957) method. Total volatile fatty acids (TVFA's) in rumen liquor were measured according to stem distillation procedure as described by Warner (1964). Rumen buffering capacity (their ability to resist $\mathrm{pH}$ change) was also determined as milli-equivalents $(\mathrm{mE})$ of hydrochloric acid required to change the $\mathrm{pH}$ of $100 \mathrm{ml}$ of rumen liquor to 4.5 according to Jasaitis et al. (1987).

Carcass characteristics:

Three lambs from each group were slaughtered at the end of the experiment to compare carcass characteristics and the anatomical aspects of the digestive tract. Lambs were slaughtered after fasting for 18 hours and fasting body weight was recorded before slaughter. The digestive tract was immediately removed by severing the esophagus which was tied at the cardia. The digestive tract was segmented by ligatures into reticulo-rumen, omasum, abomasum, small intestine and large intestine. Each segment of the digestive tract was emptied from its content, cleaned gently by tab water, then its clean fresh tissue weigh and the volume of digesta (physiological volume) was measured. Length and internal circumference of the intestinal segments was also measured.The warm carcass weight was recorded to calculate individual warm dressing percentage. Also, warm carcass length was measured. The weight of longissimus dorsi muscle (the $9^{\text {th }}, 10^{\text {th }}$ and $11^{\text {th }}$ ribs) and their measurements were recorded. Loin cut, kidney fat, mesenteric fat weights and yield grade were also measured.Yield grade was calculated as $=(10 \times$ fat thickness inch $)+0.04$ according to USDA, (1992) .

\section{Chemical analysis:}

Proximate analysis (DM, CP, CF, EE and ash) of feedstuffs and feces were determined according to A.O.A.C. (1990). The samples of feedstuffs and feces also were analyzed for fiber fractions according to the procedures of Van Soest, et al. (1991) to determine neutral detergent fiber (NDF), acid detergent fiber (ADF) and acid detergent lignin (ADL). Cellulose was calculated as $=$ ADF-ADL and Hemicellulose as $=$ NDF-ADF. Non-fibrous carbohydrates (NFC) were calculated as: NFC\% $=\mathrm{OM}-(\% \mathrm{NDF}+\% \mathrm{CP}+$ \%EE) (Calsamiglia et al., 1995).

For judging the quality of berseem silage, color and odder of silages were examined and samples were taken for chemical analysis. Silage samples were extracted using $20 \mathrm{~g}$ homogenized wet materials with $100 \mathrm{ml}$ distilled water in warm blender for 10 minutes (Waldo and Schultz, 1956). The homogenized samples were filtered through double layers of cheese cloth and filter paper until it becomes clear. Then the filtrate was used to determine silage $\mathrm{pH}$ directly by using digital $\mathrm{pH}$ meter. Lactic acid concentration was determined in silage juice colorimetric according to Barker and Summerson (1941).

\section{Statistical analysis:}

Data of the study were analyzed using the General Linear Model (GLM) of SAS (2004). Data of nutrients digestibility, feeding values and carcass traits were analyzed using one way classification model included treatment 
Gabr, A. A. et al.

effect. Whereas, body weight, daily weight gain, relative growth rate, blood constituents and rumen parameters were subjected using two way analysis of variance model included treatment, time and their interaction. Differences among the overall means were done using Duncan's multiple range test (Duncan, 1955).

\section{RESULTS AND DISCUSSION}

The silage contained $80.66 \%$ OM, $26.77 \%$ NFE, $27.29 \%$ ADF, $43.58 \%$ NDF and $18.2 \%$ NFC (Table 1), which was slightly lower than hay. Whereas, silage had higher $\mathrm{CP}, \mathrm{EE}$ and $\mathrm{CF} \%$ than hay. Conservation of berseem silage was a good, as shown by the low pH value (4.2) and low concentration of $\mathrm{NH} 3-\mathrm{N}(6.3 \%)$ and moderate level of lactic acid (2.86\%). According to Demarquilly (1990), fermentation of high- moisture silages (<30\% DM) with $\mathrm{pH}$ value of 4.0 and $<5$ to $7 \% \mathrm{NH}_{3}-\mathrm{N}$ is considered excellent.

\section{Growth performance:}

Data in Table (2) showed the initial and final weight, as well as growth rate, intake of dry matter as total and per every one $\mathrm{kg}$ daily gain. The initial weight was nearly similar between groups, whilst the final weigh of silage group (BSF) was higher than control one that fed hay as a main source of roughage but without significant differences (51.0 vs. $43.7 \mathrm{~kg})$. Therefore, the total gain of BSF was greater than control by about $37.7 \%$ (being 28.5 vs. $20.7 \mathrm{~kg}$ ). The targeted final BW was $45 \mathrm{~kg}$, but lambs fed BSF were heavier (being $51 \mathrm{~kg}$ ) than those fed control ration, probably because of more efficient utilization and good quality of silage used compared with control ration. Daily weight gain (DWG) of BSF lambs group was higher $(P<0.01)$ significantly than those in control group (being $0.155 \mathrm{vs} .0 .109 \mathrm{~kg} / \mathrm{d}$ ).

Similarly, relative growth rate $(R G R)$ was significantly $(P<0.01)$ greater in lambs fed BSF ration than control. The rate of both DWG and RGR was elevated $(P<0.01)$ significantly in lambs fed BSF ration with the advancement of the age especially in the last two months (Fig. 1). During the first 3 months, the rate of DWG and RGR was greater in control than BSF, while in the last 3 months of the trial lambs of BSF group gained faster than control as a compensatory growth. This could be due to that lambs consumed little quantity in the first month and elevated gradually to the maximum intake of silage. The growth rate in present study was in the range of previous studies (Butler, 1985; Vipond, 1998 and Speijers et al., 2005) who proposed that the growth rate of lambs fed clover silages plus cereals ranged between 100 $150 \mathrm{~g} / \mathrm{d}$.

The main average of TDMI allover the experimental period was 1.219 and $1.156 \mathrm{~kg}$ for control and BSF, respectively which was ranged between 3.1 and $3.3 \%$ of BW. The amount of TDMI / $\mathrm{kg}^{0.75}$ was slightly lower in BSF than control $\left(76.2\right.$ vs. $81.6 \mathrm{~g} / \mathrm{kg}^{0.75}$ ) that agreed with those reported by Etheridge et al. (1993) who found higher intakes of $77-81 \mathrm{~g} / \mathrm{kg} \mathrm{LW} \mathrm{LW}^{0.75} / \mathrm{day}$ when lucerne silage was offered to sheep. Feed conversion ( $\mathrm{kg} \mathrm{DMl} / \mathrm{kg}$ gain) of lambs fed BSF ration was better than those of control lambs (8.56 vs. $12.46 \mathrm{~kg}$ ). Also, Speijers et al. (2005) showed that feed conversion of lambs 
fed red clover silage was $8 \mathrm{~kg}$ feed $/ \mathrm{kg}$ gain while it was poorer $(16.6 \mathrm{~kg}$ feed/ $\mathrm{kg}$ gain) in lambs fed lucerne silage.

Table (2): Growth performance of growing lambs fed ration containing berseem silage treated with formic acid compared with traditional farm ration.

\begin{tabular}{|c|c|c|c|c|c|c|}
\hline \multirow{2}{*}{ Items } & \multirow{2}{*}{ Control group } & \multirow{2}{*}{ BSF group } & \multirow{2}{*}{$\pm \mathrm{SE}$} & \multicolumn{3}{|c|}{ Significance } \\
\hline & & & & Trt & Time & Trt*Time \\
\hline No. lambs & 6 & 6 & & & & \\
\hline Initial weight, kg & 23.0 & 22.5 & 1.68 & NS & ** & NS \\
\hline Final weight, kg & 43.7 & 51.0 & 1.68 & - & - & - \\
\hline Total gain, kg & 20.7 & 28.5 & - & - & - & - \\
\hline Daily gain, kg & 0.109 & 0.155 & 0.011 & ** & $\star \star$ & $\star \star$ \\
\hline $\mathbf{R G R}^{1}, \%$ & 0.456 & 0.693 & 0.047 & ** & $\star \star$ & ** \\
\hline TDMI, kg & 1.219 & 1.156 & - & - & - & - \\
\hline TDMI/ BW, \% & 3.33 & 3.10 & - & - & - & - \\
\hline g DMI/kg & 81.6 & 76.2 & - & - & - & - \\
\hline $\begin{array}{l}\text { Feed conversion, } \\
\text { (kg DMl/kg gain) }\end{array}$ & 12.46 & 8.56 & - & - & - & - \\
\hline
\end{tabular}
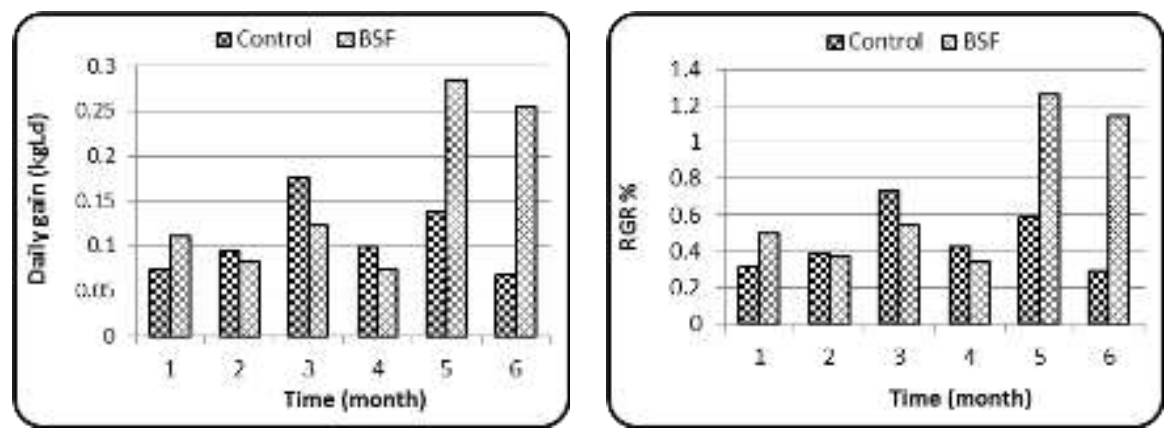

Fig. (1): Daily weight gain and relative growth rate of growing lambs at different age months as affected by tested rations.

The results are in agreement with Graham et al. (1992) who found similar values of total intake, DWG and feed efficiency of growing lambs fed clover silage plus different levels of grains. The improvement of growth rate and feed conversion by feeding experimental silage could be due to better silage quality in the present study, which is accordance with Thomas (1987); Petit and Castonguay (1994). The crude protein intake (CPI) and ME intake were significantly $(\mathrm{P}<0.01)$ greater in BSF ration than control (Table 4) that was directly related to DWG, which in accordance with (Graham et al., 1992). Also, CPI in BSF ration $(0.162 \mathrm{~kg} / \mathrm{d})$ was higher than the maintenance of $\mathrm{CP}$ to achieve daily growth rates of $150 \mathrm{~g}$ (NRC, 1985).

The profit and economic efficiency of growing lambs are presented in Table (3). The average total cost per lamb was 1.484 and $1.413 \mathrm{LE} / \mathrm{d}$ for control and BSF rations, respectively. Whereas, total price of gain was 1.96 and 2.79 LE/d/lamb for control and BSF group, respectively. Therefore, the 
Gabr, A. A. et al.

profit as total cost/ lambs was higher in BSF than control ration (1.377 vs. $0.476 \mathrm{LE})$ and the economic efficiency was $97.5 \%$ in BSF vs. $32.1 \%$ in control ration. These findings are in agreement with Abd EL-Hady (2012) who found that the economic efficiency of lambs fed berseem silage treated with corn meal or microorganisms mixture, was higher than control ration based on hay (98.6 vs. $62.0 \%)$.

Table (3): The profit and economic efficiency of growing lambs fed tested rations.

\begin{tabular}{|l|c|c|}
\hline Items & Control & BSF \\
\hline Price / kg DM, LE & 1.217 & 1.222 \\
\hline DMI, kg/d & 1.219 & 1.156 \\
\hline Total cost, LE/d & 1.484 & 1.413 \\
\hline ADG, kg/d & 0.109 & 0.155 \\
\hline Price of daily gain, LE & 1.96 & 2.79 \\
\hline Profit (LE) as total cost/lamb & 0.476 & 1.377 \\
\hline Economic efficiency, \% & 32.1 & 97.5 \\
\hline
\end{tabular}

Market price $\mathrm{pt} / \mathrm{kg}$ fresh of : $\mathrm{CFM}=174 ; \mathrm{BH}=74 ; \mathrm{BSF}=23$ and $\mathrm{kg}$ live body weight gain = 18.00 LE; Economic efficiency \% = (Price of DG - Daily feed cost)/ Daily feed cost x 100.

Digestibility and feeding value:

Data of digestion coefficients and feeding values of experimental rations are presented in Table (4). The total DMI of BSF ration was significantly higher $(P<0.05)$ than control during the digestion trial $(1.012$ vs. $0.824 \mathrm{~kg} / \mathrm{d})$, which resulted in increasing $(\mathrm{P}<0.01) \mathrm{CPI}$ and MEI in BSF than control.

Table (4): Nutrients digestibility and feeding values of experimental rations.

\begin{tabular}{|l|c|c|c|c|}
\hline ttems & Control & BSF & SE & Prob. \\
\hline Lambs No. & 3 & 3 & - & - \\
\hline TDMI, kg/d & 0.824 & 1.012 & 0.02 & 0.002 \\
\hline TDMI/BW, \% & 2.08 & 2.64 & 0.14 & 0.132 \\
\hline CPI, kg/d & 0.130 & 0.171 & 0.003 & 0.002 \\
\hline MEl, Mcal/d & 1.74 & 2.27 & 0.03 & 0.002 \\
\hline Nutrient digestibility, \%: & & & & \\
\hline DM & 60.9 & 61.5 & 0.95 & 0.717 \\
\hline OM & 62.9 & 70.4 & 0.68 & 0.002 \\
\hline CP & 60.5 & 63.4 & 1.30 & 0.185 \\
\hline EE & 62.4 & 69.1 & 0.81 & 0.004 \\
\hline CF & 64.0 & 70.8 & 1.10 & 0.012 \\
\hline NFE & 63.3 & 73.0 & 0.79 & 0.001 \\
\hline NDF & 53.9 & 64.7 & 0.95 & 0.001 \\
\hline ADF & 40.8 & 49.2 & 1.82 & 0.031 \\
\hline ADL & 12.7 & 17.0 & 0.73 & 0.014 \\
\hline Hemicellulose & 71.7 & 85.3 & 2.14 & 0.011 \\
\hline Cellulose & 53.0 & 63.4 & 2.60 & 0.047 \\
\hline NFC & 74.5 & 78.5 & 2.27 & 0.007 \\
\hline Feeding value: & & & & \\
\hline TDN\% & 59.2 & 63.0 & 0.67 & 0.016 \\
\hline DCP\% & 9.50 & 10.7 & 0.22 & 0.017 \\
\hline ME, Mcal/kg & 2.11 & 2.24 & 0.024 & 0.016 \\
\hline NE', Mcal/kg & 1.33 & 1.42 & 0.016 & 0.016 \\
\hline RFQ & 100.2 & 135.3 & 7.28 & 0.027 \\
\hline QI & 1.35 & 1.79 & 0.091 & 0.027 \\
\hline NE (Mcalkg) & & & \\
\hline
\end{tabular}

NE $(\mathrm{Mcal} / \mathrm{kg})=($ TDN\% $\times 0.0245)-0.12 \quad(\mathrm{NRC}, 2001)$

${ }^{2} \mathrm{RFQ}$ (relative feeding quality $)=(\mathrm{DMI} \%$ of BW $) \times($ TDN\% of DM) $/ 1.23$ (Moore, 1994)

${ }^{3}$ QI (Quality Index) $=0.0125 \times$ RFQ +0.097 (Moore, 1994) 
The results are in agreement with those reported by Spejers et al. (2005) who found that average intake of silage DM, total DM, CP intake and ME intake was higher for lambs fed the red clover silage versus that for lambs offered the lucerne and ryegrass treatment. The digestion coefficient of most nutrients was higher $(\mathrm{P}<0.05)$ in $\mathrm{BSF}$ ration than control. Moreover, digestibility of DM and CP tend to be higher in BSF than control ration but without significant differences.

Values of TDN\%, DCP\%, ME and NE were greater $(\mathrm{P}<0.05)$ in BSF ration than control. Similarly, the relative feeding quality (RFQ) and quality index (QI) were $(P<0.05)$ higher in $B S F$ than control ration that owing to the advantage of berseem silage quality compared with hay. The difference between BSF and control ration in RFQ and QI values translated its impact on growth rates (Moor and Kunkle, 1995). The results are in accordance to those by Abd El- Hady et al. $\left(2012_{a, b}\right)$.

\section{Rumen traits:}

The rumen liquor parameters of lambs are given in Table (5). The $\mathrm{pH}$ and calculated eNDF values were $(\mathrm{P}<0.01)$ greater in lambs fed BSF ration than control (being 6.9 and 34.8 vs. 6.54 and 26.3 for BSF and control groups, respectively). The highest values $(\mathrm{P}<0.01)$ of $\mathrm{pH}$ and eNDF were at zero time (before feeding) and there were declined after feeding at $2 \mathrm{hr}$ and then began to elevate again. The interaction between treatment and time of sampling was not significant for any ruminal traits. Similar trend was found with $\mathrm{NH}_{3}-\mathrm{N}$, TVFA's and buffering capacity values, which was higher $(\mathrm{P}<0.05)$ with lambs fed BSF ration than control. The greater level of $\mathrm{NH}_{3}-\mathrm{N}$ in BSF could be resulted in higher percent of CP and DCP in berseem silage than hay, which agreed with Hussein et al. (1995) and Ead et al. (2006). Concentration of NH3-N and TVFA's was elevated significantly $(\mathrm{P}<0.01)$ after feeding (2 hr) and thereafter it was declined gradually, which was inaccordance with kinetic $\mathrm{pH}$ value. Whereas, buffering capacity had a contrary trend that declined $(\mathrm{P}<0.01)$ significantly after feeding $(2 \mathrm{hr})$ and thereafter it was increased gradually.

Table (5): Rumen liquor parameters of lambs fed experimental rations.

\begin{tabular}{|c|c|c|c|c|c|}
\hline Items & $\mathrm{pH}$ & eNDF\% & $\mathrm{NH}_{3}-\mathrm{N}(\mathrm{mg} / \mathrm{dl})$ & $\begin{array}{c}\text { TVFA's (ml } \\
\text { eq/dl) }\end{array}$ & $\begin{array}{l}\text { Buffering } \\
\text { Capacity }\end{array}$ \\
\hline Control ration & 6.54 & 26.3 & 14.3 & 5.58 & 6.71 \\
\hline BSF ration & 6.90 & 34.8 & 16.0 & 6.94 & 8.21 \\
\hline \pm SE & 0.07 & 1.61 & 0.33 & 0.42 & 0.24 \\
\hline \multicolumn{6}{|c|}{ Sampling time (hr) } \\
\hline $\begin{array}{l}0 \\
\end{array}$ & $7.05^{\mathrm{a}}$ & $38.5^{\mathrm{a}}$ & $12.4^{\mathrm{C}}$ & $4.67^{b}$ & $8.66^{a}$ \\
\hline 2 & $6.40^{c}$ & $23.1^{\mathrm{c}}$ & $18.0^{\mathrm{a}}$ & $7.28^{a}$ & $6.62^{b}$ \\
\hline 4 & $6.70^{b}$ & $30.2^{b}$ & $15.1^{b}$ & $6.83^{a}$ & $7.11^{b}$ \\
\hline ISE & 0.085 & 1.98 & 0.41 & 0.52 & 0.29 \\
\hline \multicolumn{6}{|l|}{ Significance } \\
\hline Trt & $\star *$ & ** & ** & * & ** \\
\hline Time & ** & ** & ${ }^{\star *}$ & ${ }^{\star *}$ & ** \\
\hline Trt*Time & NS & NS & NS & NS & NS \\
\hline
\end{tabular}

eNDF\% $\%(\mathrm{pH}-5.425) / 0.04229$ Fox et al. $(2000) \quad{ }^{\star} \mathrm{P}<0.05 ;{ }^{* \star} \mathrm{P}<0.01 ; \mathrm{NS}=$ non-significant $a, b$ and $c$ lest square means in the same column with different superscript differ significantly $(P<0.01)$ 
Gabr, A. A. et al.

Earlier workers found that both digestibility and protein content of ration had a significant effect on the concentration of TVFA's in the rumen liquor (Topps, 1964). Similar trend and values of $\mathrm{pH}$, eNDF and VFA's were found by Sharaf (2008); Abou El-enin (2005) and Abd El-Hady et al. (2012a,b). On the other side, El- Shaer et al. (2001) found that ruminal $\mathrm{NH}_{3}-\mathrm{N}$ and TVFA's did not differ significantly by feeding berseem hay or halophytic silage plus concentrate.

\section{Blood metabolite status:}

Data of the concentration of blood metabolites are presented in Table (6). Plasma glucose concentration did not differ significantly between groups, but differed significantly $(P<0.01)$ with sampling time. Whereas, total protein and globulin were lower $(P<0.05)$ significantly in lambs fed BSF ration than control. The ration of albumin: globulin was higher $(P<0.05)$ in BSF group than controland declined $(P<0.05)$ significantly with sampling time. The concentration of AST and ALT as liver function indicators was greater $(P<$ 0.05 ) in control than BSF group and differed significantly with sampling time. Whereas, AST/ALT ratio and plasma createnine (as a kidney function indicator) were not affected by ration type, time or their interaction. All data of metabolic profile were below the critical level and within the normal levels as reported by Rokha (1985); Allam et al. (1997); Fraser and Moorby (1998) and Abdou (1998). The liver function and immune response could be indicated to healthy status treated lambs.

Table (6): Blood metabolites of growing lambs fed berseem silage treated with formic acid compared with traditional farm ration.

\begin{tabular}{|c|c|c|c|c|c|c|c|c|c|}
\hline & \multicolumn{2}{|c|}{ Glucose T. Prot. } & Alb. & Glob. & A/G r. & AST & ALT & AS/AL r. & Creat. \\
\hline \multicolumn{10}{|l|}{ Treatments: } \\
\hline Control ration & 48.5 & 5.70 & 2.94 & 2.76 & 1.14 & 37.0 & 9.44 & 3.95 & 0.86 \\
\hline BSF ration & 47.7 & 5.23 & 3.11 & 2.12 & 1.79 & 30.4 & 7.17 & 4.65 & 0.84 \\
\hline ISE & 1.88 & 0.146 & 0.076 & 0.134 & 0.17 & 2.15 & 0.38 & 0.35 & 0.027 \\
\hline \multicolumn{10}{|c|}{ Sampling time (month): } \\
\hline 1 & $48.6^{b}$ & 5.34 & $3.38^{\mathrm{a}}$ & $1.96^{\mathrm{C}}$ & $2.02^{\mathrm{a}}$ & $31.2^{\mathrm{bc}}$ & $8.07^{b}$ & 4.09 & 0.80 \\
\hline 2 & $59.7^{a}$ & 5.18 & $2.95^{\mathrm{b}}$ & $2.23^{\mathrm{bc}}$ & $1.68^{\mathrm{ab}}$ & $34.9^{b}$ & $10.1^{\mathrm{a}}$ & 3.57 & 0.85 \\
\hline 3 & $38.9^{c}$ & 5.95 & $2.97^{b}$ & $2.98^{\mathrm{a}}$ & $1.03^{b}$ & $24.0^{c}$ & $5.34^{c}$ & 4.87 & 0.82 \\
\hline 4 & $45.3^{\mathrm{bc}}$ & 5.39 & $2.82^{b}$ & $2.58^{\mathrm{ab}}$ & $1.12^{b}$ & $44.5^{a}$ & $9.57^{a}$ & 4.66 & 0.94 \\
\hline ISE & 2.66 & 0.21 & 0.11 & 0.189 & 0.24 & 3.04 & 0.54 & 0.50 & 0.04 \\
\hline \multicolumn{10}{|l|}{ Significance: } \\
\hline Trt & NS & * & NS & $\star \star$ & * & * & ** & NS & NS \\
\hline Time & ** & NS & $* *$ & ** & * & ** & ** & NS & NS \\
\hline Trt*Time & NS & NS & NS & NS & NS & NS & NS & NS & NS \\
\hline
\end{tabular}

\section{Carcass characteristics:}

Least square means of carcass characteristics of lambs are shown in Table (7). Hot carcass weight of lambs fed BSF was higher $(P<0.05)$ than control (30.2 vs. $27.3 \mathrm{~kg})$. Whereas, carcass length and hot dressing\% did not differ significantly by silage feeding. The loin cut was slightly higher, whilst longissimus dorsi (L.D.) was significantly $(\mathrm{P}<0.05)$ heavier in BSF lambs than control. Fat thickness of L.D and kidney fat were greater in BSF lambs than 
control but without significant differences. As well as, mesenteric fat was higher ( 0.890 vs. $0.425 \mathrm{~kg})$ in BSF group than that in control group. Carcass of BSF lambs were fatter actual fat thickness $(0.4 \mathrm{vs} .0 .3 \mathrm{~cm})$ resulting in higher yield grades (1.62 vs. 1.22) than carcass from control lambs. The anatomy data of gastrointestinal tract indicated that weight of digestive tract, omasum and large intestine did not differ between groups. Otherwise, reteculo-rumen, small intestine and gastrointestinal content and their percent of BW were higher in control than those in BSF lambs, but without significant differences. Whereas, abomasum weight and percent of BW were lower $(P<0.05)$ in control than BSF lambs. The carcass results are in agreement with Petit and Castonguay (1994) who fed lambs silage with or without concentrate or fish meal and obtained similar trend but lower values of carcass weight, dressing\% and fat thickness. Similar results were observed by Povey et al. (1990). As well as, Burke and Apple (2007) found similar values of dressing\%, fat thickness, kidney fat weight and yield grade when they compared different breed types of lambs. Rios et al. (2011) evaluated anatomy traits of different breeds of lambs and found similar trend as that obtained in the present study except for lower values of gastrointestinal content and large intestine.

Table (7): Carcass characteristics in growing lambs fed CFM plus berseem hay or silage treated with formic acid.

\begin{tabular}{|c|c|c|c|}
\hline Items & Control & BSF & $\pm \mathrm{SE}$ \\
\hline \multicolumn{4}{|l|}{ Carcass characteristics: } \\
\hline Hot carcass, $\mathrm{kg}$ & 27.3 & 30.2 & $0.656^{*}$ \\
\hline Carcass length, cm & 51.5 & 51.0 & 0.42 \\
\hline Hot dressing \% & 51.9 & 52.8 & 2.37 \\
\hline Loin cut, $\mathrm{kg}$ & 2.14 & 2.39 & 0.187 \\
\hline Longissimusdorsi(L.D), kg & 0.569 & 0.679 & $0.026^{*}$ \\
\hline L.D boonless, $\mathrm{kg}$ & 0.254 & 0.270 & 0.050 \\
\hline L.D. fat thickness, cm & 0.300 & 0.400 & 0.076 \\
\hline Yield grade $^{1}$ & 1.22 & 1.62 & 0.30 \\
\hline Kidney fat, $\mathrm{kg}$ & 0.143 & 0.240 & 0.051 \\
\hline \multicolumn{4}{|l|}{ Organs: } \\
\hline \begin{tabular}{|l} 
Mesenteric fat, $\mathrm{kg}$ \\
\end{tabular} & 0.425 & 0.890 & 0.147 \\
\hline Digestive tract, $\mathrm{kg}$ & 3.04 & 3.19 & 0.42 \\
\hline D.T \%BW & 5.50 & 5.74 & 0.59 \\
\hline Reticulo-rumen, kg & 1.44 & 1.16 & 0.117 \\
\hline R.R \%BW & 2.64 & 2.09 & 0.17 \\
\hline Omasum, kg & 0.217 & 0.226 & 0.021 \\
\hline Omasum \%BW & 0.396 & 0.407 & 0.028 \\
\hline Abomasum, kg & 0.266 & 0.395 & $0.025^{\star}$ \\
\hline Abomasum \%BW & 0.483 & 0.712 & $0.025^{* \star}$ \\
\hline Small Intestine, kg & 1.35 & 1.18 & 0.138 \\
\hline S. Int. \%BW & 2.46 & 2.12 & 0.25 \\
\hline Large Intestine & 0.237 & 0.229 & 0.043 \\
\hline L. Int. \%BW & 0.43 & 0.41 & 0.068 \\
\hline Gastrointestinal content, kg & 9.81 & 9.69 & 1.41 \\
\hline Gastroint. \%BW & 17.72 & 17.43 & 1.86 \\
\hline
\end{tabular}

Yield grade $=(10 \mathrm{x}$ fat thickness inch) +0.04 (USDA, 1992).

${ }^{*} \mathrm{P}<0.05 ;{ }^{* *} \mathrm{P}<0.01$ 


\section{Conclusion:}

From the forgoing results, it could be concluded that growing lambs raised on wilted (for $24 \mathrm{hr}$ ) BSF plus CFM had the highest growth performance, feed conversion, economic efficiency, quality index, feed utilization, normal health status and better carcass traits compared with traditional rising on hay plus CFM ration.

\section{REFERENCES}

A.O.A.C. (1990). Association of Official Analytical Chemists Methods of Analysis. $16^{\text {th }}$ ed. Washington, D.C., USA.

Abd El-Hady, (2012). Effect of seasonal changes and type of roughage on: Igrowth performance, metabolic activity and carcass characteristics of crossbreed lambs. J. Animal and Poultry Prod., Mansoura Univ., Vol. 3 (4): 167-181.

Abd El-Hady, M.A.A.; Gabr, A.A.; El-Ayouty, S.A. and Shahin, M.A. (2012 ${ }_{\mathrm{a}}$ ). Effect of physical and chemical treatments on berseem silage quality, nutritive values, rumen fermentation and blood metabolites of rams. J. Animal and Poultry Prod., Mansoura Univ., Vol. 3 (5):267-288.

Abd El-Hady, M.A.A.; El-Ayouty, S.A. and Sayed, S.K. (2012b). Effect of seasonal changes and type of roughage on: II- nutritive values, rumen fermentation and blood metabolites of crossbreed lambs. J. Animal and Poultry Prod., Mansoura Univ., Vol. 3 (4): 183-198.

Abdou, A. R. (1998). Utilization of organic wastes as animal feed in Sinai. M.Sc. Thesis, Faculty of Agriculture, Cairo University, Egypt.

Abou EL-Enin,Ebtehag I.M. (2005). Nutritional evaluation of different treatments in silage production for ruminants feeding. Ph.D. Thesis Ain Shams University.

Allam, S.M.; Hanfy, M.A.; Goma, I.A. and Abdou, A.M. (1997). Effect of ammoniation on date seeds utilisation in dairy rations. In: Proceeding of the $6^{\text {th }}$ Conference on Animal Nutrition, El Minia (Egypt), 17-19 November.

Barker, S. B. and Summerson. W. H. (1941). The colorimetric determination of lactic acid in biological material. J. Biol. Chem. 137: 537-554.

Burke, J. M and Apple, J. K (2007). Growth performance and carcass traits of forage-fed hair sheep wethers. Small Ruminant Research 67: 264-270

Butler, G., (1985). Silage for lamb finishing. In: Maxwell, T.J., Gunn, R.G. (Eds.), Hill and Upland Livestock Production, Occasional Publication no. 10. British Society of Animal Production, Edinburgh, UK, pp. 140141.

Calsamiglia, S.; Stern, M.D. and Firkins, J.L. (1995). Effects of protein source on nitrogen metabolism in continuous culture and intestinal digestion In Vitro. J. Anim. Sci., 73: 1819.

Conway, E.F. (1957). Micro-diffusion analysis and Volumetric Error. Rev. Ed. Lock wood, London.

Demarquilly, C. (1990). Utilisation des conservateurs: Quand et pourquoilesutiliser. Resultatszootechniquesobtenus avec desensilagesd'herbe prepares avec des conservateursefficaces. In: Int. Silage Symp., Rouyn-Noranda, Quebec, Canada. p 93. 
Duncan, D.B. (1955). Multiple range and multiple F tests. Biometrics, 11: 1.

Ead, H.M.E. and Eman H.M. Maklad (2006). Influence of feeding different levels of soybeen meal in growing Friesian calves ration on: 1. Productive performance after weaning. J. Agric. Sci., Mansoura Univ., 31(3):1335-1351.

El-Shaer H.M., Fahmy, A.A.; Abdul Aziz, G.M Shalaby, A.S. and Abd ElGawad, A.M. (2001). Nutritional evaluation of non- conventional fattening diets fed to sheep under arid conditions of Egypt. Proceeding of International Conference, Tunisia, 8-10 Nov.

Etheridge, M.O.; Stockdale, C.R.; Cranwell, P.D. (1993). Influence of method of conservation of lucerne on factors associated with voluntary intake in sheep. Aust. J. Exp. Agric. 33, 417-423.

Fox, D.G.; Tylutki, T.P.; Van Amburgh, M.E.; Chase, L.E.; Pell, A.N.; Overton, T.R.; Tedeschi, L.O.; Rasmussen, C.N. and Durbal, V.M. (2000). The net carbohydrate and protein system for evaluating herd nutrition and nutrient excretion. Anim. Sci. Mimeo 213, Dpt. Anim. Sci., Cornell Univ., 130 Morrison Hall, Ithaca, New york 14853.

Frame, J.; Charlton, J.F.L. and Laidlaw, A.S. (1998). Temperate forage legumes. $C A B$ International, Wallingford, Oxon, UK.

Fraser, M.D.;Fychan, R. and Jones, R. (2000). Voluntary intake, digestibility and nitrogen utilization by sheep fed ensiled forage legumes. Grass Forage Sci. 55, 271-279.

Fraser, M.D. and Moorby, J.M. (1998). Plasma biochemical values in the guanaco (Lama guanicoe) and a comparison with the sheep. Anim. Sci. 66, 209-216.

Graham, R.T.;Kingery, J.L. and Volland, L.A. (1992). Livestock and fores: management interactions, pp. 351-364. In: H.C. Black (Ed.). SiJvicultural approaches to animal damage management in Pacific Northwest forests. USDA Forest Serv. Gen. Tech. Rep, PNW GTR287.

Haigh, P.M. (1988). The effect of wilting and silage additives on the fermentation of autumn made grass silage ensiled in bunkers on commercial farms in south wales. Grass Forage Sci., 43:337-345.

Hussein, H.S.; Camron, M.R.; Fahey, G.C.;Merchen, Jr. N.R. and Chark, J.H. (1995). Influence of altering ruminal degradation of soybean meal protein on In-situ ruminal fiber disappearance of forage and fibrous byproducts. J. Anim Sci. 73:2428

Jasaitis, D.K.; Wohlt, J.E. and Evans, J.I. (1987). Influence of fed ion content on buffering capacity of ruminant feedstuffs in vitro. J. Dairy Sci., 70:1391.

McDonald, P; Henderson, N. and Heron, S. (1991). The biochemistry of silage. $\left(2^{\text {nd }}\right.$ Ed. $)$, Aberystwyth, UK, Chalcombe Publications.

Moore, J.E. (1994). Forage quality indices: development and application. P. 977-998.

Moor, J.E. and Kunkle, W.E. (1995). Improving forage supplementation programs for beef cattle. Pp 65-74. In 6th Annual Florida Rumination Symposium. Gaianesville.

National Research Council (NRC) (1985). Nutrition requirements of sheep. $6^{\text {th }}$ revised Ed. National Academy Press. Washington. D.C. 
National Research Council (2001). Nutrient requirements of dairy cattle, seventh Revised Edition. National Academy Press, Washington, D.C.

Petit, H. V. and Castonguay, F. (1994). Growth and Carcass Quality of Prolific Crossbred Lambs Fed Silage with Fish Meal or Different Amounts of Concentrate J. h i m . Sci. 72:1849-1856

Povey, G.M.; Webster, G.M. and Weekes, T.E.C. (1990). The response of silage fed Scottish Blackface lambs to increasing level of fish meal supplementation with or without additional barley. In: C.F.R. Slade and T.J.L. Lawrence (Ed.) New Developments in Sheep Production. Occ. Publ. Br. SOC. h i m . Prod. No. 14. Pp 157-161. Edinburg, U.K.

Reed, K.F.M. (1979). A note on the feeding value of grass and grass/clover silages for store lambs. Anim. Prod. 28, 271-274.

Rios, F.G.; Gomez-Vazquez, A.; Pinos-Rodriguez, J.M.; Garcia-Lopez, J.C.; Estrada-Angulo, A.; Hernandez-Bautista, J. and Portillo, J.J. (2011). Effect of breed on performance and carcass characteristics of Mexican hair sheep. South African J. Anim. Sci., 41:275-279.

Rokha, G.M. (1985). Effect of concentrate deprivation on animal health and production. MSc Thesis, Faculty of Veterinary Medicine, Cairo University, Egypt.

SAS (2004). SAS User's Guide, SAS (Statistical Analysis System) Institute, Cary, NC.

Sharaf, K.M.I. (2008). Studies on the use of silage in animal feeding. M.Sc. Thesis, Mans. Univ.

Snyman, L.D. and Joubert, H.W. (1996). Effect of maturity stage and method of preservation on the yield and quality of forage sorghum. Anim. Feed Sci. Techn., 57: 63-73.

Speijers, M.H.M.; Fraser M.D.; Theobald V.J. and Haresign W. (2005). Effects of ensiled forage legumes on performance of store finishing lambs Animal Feed Science and Technology 120: 203-216

Thomas, C. (1987). Factors affecting substitution rates in dairy cows on silage based rations. In: W. Haresign and D.J.A. Cole (Ed.) Recent Advances in Animal Nutrition, pp 205-218. Buttenvorths, London.

Topps, J.H. (1964). Volatile fatty acids in the rumen of African sheep given a variety of low protein diets. Anim. Prod., 6:91

USDA, (1992). United States standards for grades of lamb, yearling mutton, and mutton carcasses. USDA, AMS, Washington, DC, pp. 1-15.

Van Soest, P.J.; Robertson, H.B. and Lewwis, B.A. (1991). Method of dietary fiber and non-starch polysaccharides in relation to animal material. $\mathrm{J}$. Dairy Sci. 74: 3583.

Vipond, J.E. (1998). Producing farm assured lamb profitably. In: SAC Booklet. Scottish Agriculture College, Edinburgh, Scotland, UK, pp. 120.

Waldo, D.R. and Schultz, L.H. (1956). Lactic acid production in the rumen. J. Dairy Sci., 39:1455.

Warner, A.C.I. (1964). Production of volatile fatty acids in the rumen, methods of measurements. Nutr. Abst. \&Rev., 34:339.

Webster, G.M.; Povey, G.M. (1990). Nutrition of the finishing lamb. In: Slade, C.F.R., Lawrence, T.L.J. (Eds.), New Developments in Sheep Production. Occasional Publication no. 14. British Society of Animal Production, Malvern, UK, pp. 71-82. 
معدلات النمو وقياسات الام ومواصفات الأبيحة للحملان النامية المنشأة على عليقة

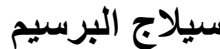

أحمد عبدالزازق جبرَ'، ماجد عبدالهادى عبدالعزيز عبدالهادى2، السيد أحمد العيوطى1،

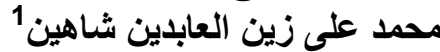

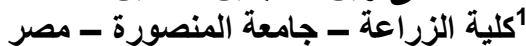

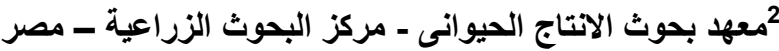

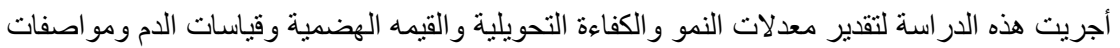

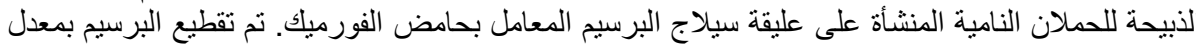

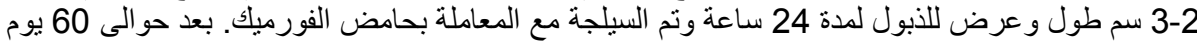

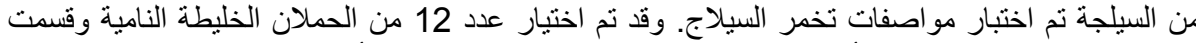

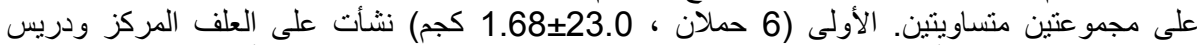

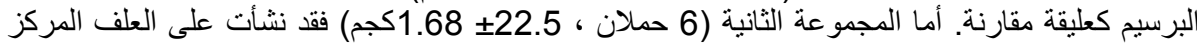

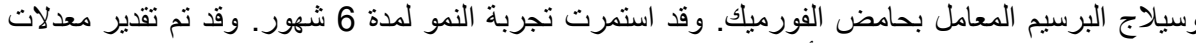

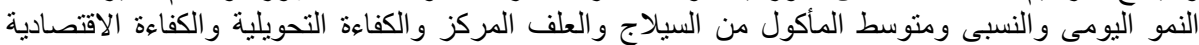

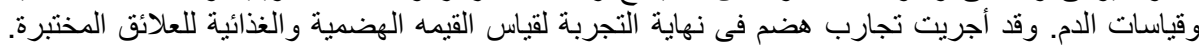

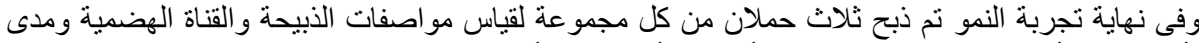

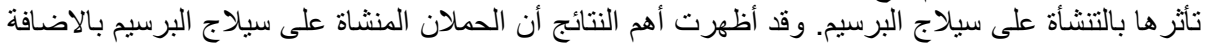

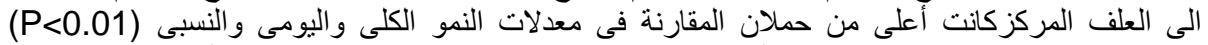

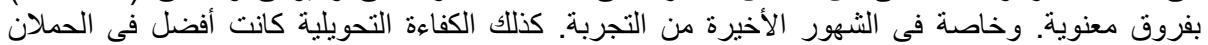

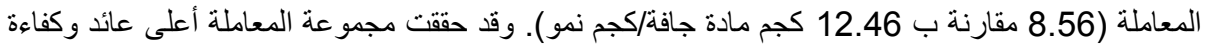

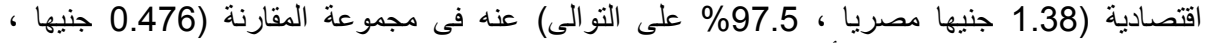

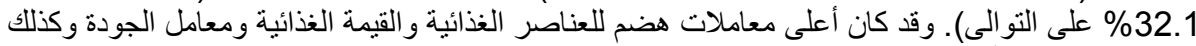

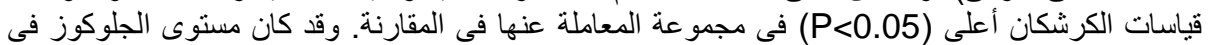

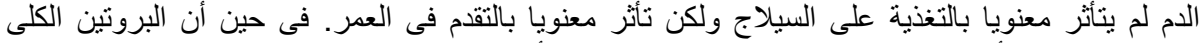

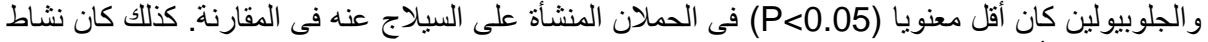

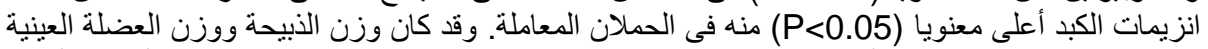

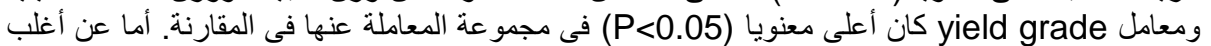

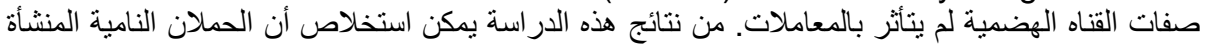

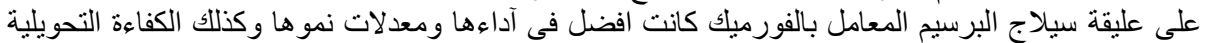

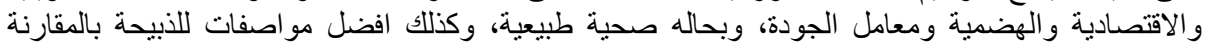
بالحملان المنثأة على العليقة التقليدية الجافة المعتدة على دريس البرسيه.

كلية الزراعة - جامعة المنصورة مركز البحوث الزراعية
قام بتحكيم البحث

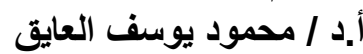

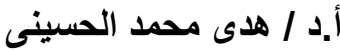

